CIRR XXIII (78) 2017, 149-168

ISSN 1848-5782

UDC 338. 1:327|5101

DOI 10.1515/cirr-2017-0011

\title{
The Challenge of Different Perceptions on the Belt and Road Initiative
}

Ma Junchi

\section{Abstract}

This articlel focuses on the perceptions of the Chinese and its partners on the Belt and Road Initiative. The author summarizes the existing foreign opinions about the initiative, one "inequality" of the market, three goals that China wants to achieve and two ways in which China wants to create domestic stability. In fact, the difference between foreign and Chinese perceptions is based on the relative national condition of the two sides, the perception of great powers, and the combination of domestic needs and foreign policy. Finally, the author points out that there are three paradoxes which exist in the differences between China and its partners, which is the biggest challenge of the Belt and Road Initiative.

\section{KEY WORDS:}

This paper is funded by the project of China National Fund for Social Sciences: "The $16+1$ cooperation model under the Belt and Road Initiative". 
Since the Chinese President, Xi Jinping, first announced the Belt and Road Initiative, it has developed for almost 5 years. Under this initiative, China and its partners have achieved many projects, for example, X-Xin-Ou trans-continental railways, which are important to the transportation of goods between Asia and Europe. ${ }^{2}$ The Greek Piraeus port is also another successful case, which will help to shorten transportation times, together with the China-Europe Land and Sea Express line through Macedonia, Serbia and Hungary. In Asia, China, Indonesia, Thailand and other related countries have achieved deep cooperation on high-speed rail. These big projects have drawn the world's attention to China and its Belt and Road Initiative. Considering the big size of China and the quick development of its economy in recent years, many world elites hold the view that China is a threat to the current world order, or that it will buy the world, conquer and divide Europe and so on. Responding to this situation, the Chinese government and elites from different areas did a lot of work to create opportunities for communication and exchange. However, the author thinks that China still has not grasped the way in which other countries are thinking. China is just working as a propaganda machine by repeating the same words everywhere. They are coping with problems without deeply understanding them. Accordingly, this article tries to summarize the characteristics of foreign perceptions towards the Belt and Road Initiative, mainly from the points of view of European countries. Most of the data is collected from the records of the author during conferences and private interviews, and a part of the data is from public papers. The author will point out the different ways of thinking between China and other countries, especially European countries. Lastly, the author points out the paradoxes behind the perceptions of China and its partners on the Belt and Road Initiative.

\section{Existing opinions from foreign partners on the Belt and Road Initiative}

2 The X-Xin-Ou trans-continental railway refers to several railways from Chinese mainland cities, to European cities such as Madrid and Berlin. All of these railways pass through Xinjiang province. Up to now, there are six of these kinds of railways, Yi-xin-ou, Rong ou, Shaan-xin-ou, Zheng-xin-ou, Han-xin-ou, and Yu-xin-ou. The author thinks that the Yu-xin-ou railway works better than the others, since it brings more goods, especially high value added goods, back to China. 
This section summarizes the main foreign opinions on the Belt and Road Initiative. The author organizes these into: one "inequality" between China and its Partners; three goals that China wants to achieve; two ways in which China wants to create domestic stability. These opinions focus on the goal of the Belt and Road Initiative and the ways to implement it.

\section{One "inequality" between China and its partners}

The imparity of the Belt and Road Initiative is the "inequality" in the relationships between China and its partners, that is, the "inequality" of the market. According to this opinion, many countries still suffer from the financial crisis and/or with the refugee crisis, which leads to the slow recovery of their economy. China needs to upgrade its industries and enlarge the market for its products through a great number of mergers and acquisitions, under the name of the Belt and Road Initiative. This process can easily open the internal market of another country to China. On the other hand, when these countries enter the Chinese market, they cannot do so effectively, due to the complicated situation in China, despite the fact that Chinese markets are more open than before. ${ }^{3}$ Foreign countries urge China to reduce the limitations to market access and improve intellectual property rights protection. Public procurement especially needs to be open to foreign companies. For foreign countries, the best way to achieve this is to sign an investment protection agreement with the Chinese central or local government (Brockova and Gress 2016). Moreover, the form of Chinese investment cannot meet its partners' needs. Nowadays, Chinese investment is merger and acquisitionoriented. For example, in Hungary, the only greenfield investment is the Wanhua chemical group. This investment happened in 2009, and 7 years have passed since then. On the issue of infrastructure, the Chinese investment mode is Build-Transfer (BT), which is also not preferred by other countries. According to Chinese partners, they need greenfield-investment, Engineering Procurement Construction (EPC) or Public-Private-Partnerships (PPP) models, which can use local materials, hire local labour, and boost the local economy. ${ }^{4}$ What China is doing now is totally different. In their view, traditional

3 Interview with official from the Polish Embassy in Beijing, China. Date: 5 June 2015.

4 Interview with official from Chinese Ministry of Foreign Affairs. Date: 26 January 2016. 
BT investment can maybe improve local infrastructure, but the future owner will face more risk.

These phenomena cause the impression that China wants to use the Belt and Road Initiative to maintain and enlarge the openness of others' markets to its investment and products, but at the same time, close or tighten the openness of its own market to foreigners, especially in the areas of finance, construction or communication. For those of this opinion, it means China does not want to sincerely cooperate with others when it initiated the Belt and Road project.

\section{Three goals that China wants to achieve}

The three goals that China wants to achieve are widely considered as the direct goals of the Belt and Road Initiative. This perception holds the view that the Chinese Belt and Road Initiative will directly serve the reconstruction of world order. It is also a strengthening and active signal of Xi's foreign policy in order to create a stable international environment. Nowadays, China promotes relations both eastward and westward. Eastward, China promotes relations with the USA; Westward, China enhances cooperation with Eurasian countries through the Belt and Road Initiative, especially with Germany and Russia. If these countries maintain cooperation with China, then China will avoid many difficulties during its development (Weissmann 2015). Concretely, under this perception, there are three kind of goals that China aims to achieve:

Firstly, through the Belt and Road Initiative China seeks legitimacy in the international economic and financial order. China always aims to enhance its own place in global economic management and demonstrate its ability. On the one hand, China gets a more important place in the International Monetary Fund (IMF) or the World Bank. On the other hand, China has established the New Development Bank and Asian Infrastructure Investment Bank (AIIB), which are parallel and compatible with these financial institutions. Such a goal needs the support from other countries, especially from the European Union. The EU's recognition of China's place in the international economic order is quite essential. 
many partners, a bilateral relationship with China is much more important than a multilateral one. They think that, through bilateral negotiation, China could decrease its dependency on one country while at the same time, gain importantce in China's foreign policy. This phenomenon is well illustrated in the Central and Eastern Europe (CEE) region. Every CEE country describes itself as the gateway to Western Europe or Northern Europe, to attract Chinese investment. They are worried that China will invest in its neighbors. Due to this competition for Chinese attention, many think that China will use this chance to leverage others to overlook the issue of human rights in China, or other sensitive issues. For example, the Czech Republic's official attitude towards China and 16+1 cooperation has altered due to this reason. Under the Belt and Road Initiative, pragmatic cooperation becomes more vital.

Thirdly, China uses multilateral cooperation to gain political support in the EU. Up to now, China has been actively pushing for multilateral cooperation. The $16+1$ is a focus of Chinese foreign policy towards EU. The motive behind $16+1$ is that China plans to use trade and investment in areas such as infrastructure, energy and agriculture, to serve the objectives of the Belt and Road in the West. Many elites who share this view think that after the EU does not admit the market economy status of China, China will take CEE countries as a way to broaden its diplomatic tools and form a lobby inside the EU. This is the political support that China plans to gain through the Belt and Road initiative. ${ }^{5}$

\section{Two ways in which China wants to create domestic stability}

Domestic stabilization is the final goal of the Chinese Belt and Road Initiative, shared by most Chinese elites. The biggest challenge China has faced in recent years is the structural reform of its economic model, from investment and export, to domestic consumption. Earlier in its economic history, China depended a lot on export and low-wage labor, which is unsustainable under current economic trends. The high-speed growth of GDP brought about corruption, a gap between urban and rural development, environmental pollution and so on, which makes structural reform harder. Besides that, private enterprises have large debts, and

5 This view is shared by many scholars and officials from CEE countries. However, according to the study of a scholar from Corvinus University, Hungary, the votes in the European Parliament from CEE countries have not changed a lot, which needs to be studied further. 
banks try to hide large-scale bad debts (Rudzki 2016). Another factor is that the Chinese welfare system is not effective and consistent enough to support structural reform, especially on the local level. These are the negative factors which affect domestic stabilization in China. Based on these factors, the Chinese Belt and Road Initiative serves the goal of achieving domestic stability. Elites consider that the root of Chinese foreign policy are domestic problems. There are two ways to create domestic stabilization.

One is nationalistic sentiment. China proposed the Belt and Road Initiative to fulfill the need of Chinese people's nationalistic sentiments, which is very helpful in uniting the Chinese people suffering a depressed economy. It can build a strong, investment-oriented China, which shows great interest in infrastructure, industrial parks, etc. This impression of the nation will stimulate nationalistic sentiment, which makes Chinese people focus more on long-term, strategic goals, rather than short-term profit. However, others think that nationalistic sentiment is the Sword of Damocles. China should cautiously balance, because if nationalistic sentiment is stimulated too much, then it will affect its neighbors and its own minorities. The throat of the Belt and Road Initiative is Xinjiang province, where conflicts of nationalism are serious and it will be hard to eliminate them only by economic growth. Regarding Chinese neighbors, some Islamic groups from Central Asia constantly support separatists in Xinjiang, so nationalism is a very dangerous tool with which to achieve a goal (Sørensen 2015).

The second way China might achieve domestic stability is through the Chinese government's strong role in many aspects of daily life. China uses the Belt and Road Initiative to enhance the government's effect on the economy and capacity production. Some say the Chinese government repeatedly stresses its decisive role, rather than basic role, which means government intervention will continue. Like in Chinese investment in other countries, state-owned companies play a central role. Under the capacity production cooperation plan, the Chinese government is also the main stimulator. Domestically, China uses the Belt and Road Initiative to link the provinces to the central government. Local governments try every means to define their role in the Belt and Road Initiative and boost their reputation, to get more attention from the central government. ${ }^{6}$ However, the pessimists 
hold that the efficiency of intervention is low, which sets back economic innovation and the market economy. For foreign investors, it is an uncertain signal with which to predict the direction of the Chinese economy.

In short, foreign opinions on the Belt and Road Initiative are not just limited to the initiative itself, but broadened to include speculation on the Chinese domestic market, its economic situation, its domestic stabilization and China's political ambition in the world. Additionally, the above views are not just limited to the quoted materials, they always occur during conferences, seminars, and interviews with some government officials or scholars.

\section{The root of the perceptions of China and its partners towards the Belt and Road Initiative}

\section{The difference in the overall condition of the two sides}

The "inequality" of the market is the first thing that the two sides understand differently, and it is often mentioned at every occasion about the Belt and Road. However, it is rooted in the different need and condition of the two sides.

For China, on one hand, its industries face the problems of overcapacity and low added-value, which hinders the Chinese economy. Although Chinese GDP is now increasing slowly, according to official data, these real structural problems are unsolved. It is an urgent task for China, and its biggest need. On the other hand, since the global financial crisis hightech enterprises, mainly in Europe and the USA, are suffering from a break of the capital chain, and at the same time Chinese enterprises are waiting to upgrade themselves, with a lot of money seeking investment. This is, to an extent, a historical coincidence. From this point of view, China did not "invade" or "buy" Europe. China is just acting according to the current situation and is taking advantage of historical opportunities. 
As for the method of investment, Chinese sides need to learn technological skills and produce higher added-value products as soon as possible. So, generally speaking, mergers and acquisitions are the fastest way to achieve this goal, which is a reasonable and lawful way all over the world, except for some certain areas which involve national security. Besides, Chinese enterprises will face unfamiliar regulations and markets just as foreign enterprises face in China, especially regarding the process of investment to the upper section of the industrial chain. This is unlike big western groups, who just invest in the lower part of the industrial chain, to find low-cost labor. So for the Chinese side, they will face more risk. Under this situation, mergers and acquisitions are also the safest way. To avoid risk is the common concern of companies worldwide. So we can see that the Chinese need to upgrade is not different from the needs of other companies, and its way of seeking opportunities is also common in the field of business. The USA also invested a lot and bought a lot of European companies during the financial crisis (EY report 2015). It seems that it did not catch as much attention as China did. In fact, the author thinks that the method of investment is not the real concern for European and other partners. Rather, what is of concern is a Chinese industrial upgrade by one big leap, which means China does not need to go step by step, and can just go directly from 2.0 to 4.0 through mergers and acquisitions.

Foreign partners all seek protection of knowledge, know-how, technology, and investment from the Chinese government, due to its complicated market and lack of related regulation. Or they urge China to increase its agricultural quota for imports. These are the main complaints when they come to China. It is true that the Chinese market is not so transparent or regulated as the European one, and the supervision of the quotas on agricultural products is strict and time-consuming. However, China is improving its market environment and foreign partners cannot take China as a mono-natured market. In the southern part of China, the trade environment and the government is more open. The market is more regulated and policies are more transparent, since this part of China was the pilot for the Chinese private economy during the "Reform and Open" era. Consumers there are also very open to new products. Contrary to that, the north-eastern part of China is more closed since they are still suffering from overcapacity of their industries, which was deeply influenced by the former Soviet Union style economy. In this part of China people 
and government are more closed, even to the Chinese themselves. The western part of China is now developing very fast with the support of the government, since it is an important part of the Belt and Road. So the Chinese market is large and divergent, and not in total chaos as foreign partners imagine it. As for the agricultural quotas, this is hard to get from the Ministry and State Quality Inspection Administration. Partly, this is because the paperwork and bureaucracy in these bodies is complicated and time-consuming. Partly, this is because of the small amount of agricultural products from foreign countries that enter the Chinese market. The Chinese population is large, and a small amount of product cannot even meet the needs of market promotion, and the administration is not willing to go through complicated and time-consuming procedures for a small quantity of products. This phenomenon is more common in Central and Eastern Europe. Many high-quality agricultural products from the CEE cannot enter the Chinese market, not because of quality, but because of quantity, which does not arouse the interest of the Ministry and State Quality Inspection Administration. This is why Poland and other countries always complain about a trade deficit with China. So it is the different internal conditions of China and its partners that causes the "inequality" of the market, and some misunderstanding about Chinese market.

\section{The perceptions of great powers}

The second feature of foreign opinion are the perceptions of the great powers. They consider China as a global and regional great power. This is the root of the view that the Chinese Belt and Road Initiative will directly serve the reconstruction of world order and the creation of a stable international environment and multi-polar world. Their logic is that China must be a great power now, and therefore China is capable of changing the current world order and definitely will change it. This logic, to most Eurasian countries, expresses their two concerns or expectations of great powers. Firstly, they expect China, as a great power with global influence, to not only be the motor of the world economy, but also an active actor in global geopolitical crises. Like Polish Foreign Minister Witold Waszczykowski said in a public speech in China: "Although [the] EU's Foreign and Security Policy really pays a lot of attention to the neighbors' geopolitical issues, [the] EU needs to build strategic partnership with countries beyond the EU's border. China is in the first place. Any strategic partnership, especially 
EU-China partnership, should not be limited to economic cooperation. [the] Chinese Belt and Road Initiative should go beyond the connectivity between Eurasian countries" [sic] (Waszczykowski 2016). "In fact, other countries share the same view as the Polish minister's. In the Ukrainian and Syrian crises, there are always voices urging China to choose a side to stand with. Secondly, most Eurasian countries are small countries, compared with Russia or the USA. In their history, they are deeply influenced by these traditional great powers. Even today, this influence has not stopped. So in the eyes of these countries, the phrase "great power" does not have a good connotation. Great powers will use their soft power to penetrate into local politics through NGO training, government official training, religious recognition or other tools. This kind of influence can even arouse serious security issues, like in South-Eastern European countries, Islamic groups supported by some great power or another, are a great concern for both society and governments. One of the Assistants of the Serbian Foreign Minister once said during a meeting, "Serbia is surrounded by [the] EU and NATO. Germany also pushed Northern Europe and Baltic countries for sanction to Russia. All of these harm Serbian interest and all of these are the results of big powers' influence" [sic]. ${ }^{8}$ This is how Eurasian countries think of great powers. In their eyes, China is a new great power on the rise, and definitely will use tools to get the support of international society. The Belt and Road Initiative is the tool that China chooses to utilize. To them, China's goal is legitimacy in the international economic order, and the support, or less interference on sensitive issues, from the EU. However, these goals are just in the imagination of China's foreign partners. They are neither realistic, nor appropriate for today's China.

China is indeed rising in the world, which will draw global attention. But at the same time, China is weak due to many structural problems. The rise of China is different from the time of the USA's rise, or Germany's rise. So for China, the essential principle is that it should rise peacefully, which means it should not cause problems with other countries. As mentioned above, China's final goal of the Belt and Road Initiative is to solve domestic problems, which means China knows itself well, and knows its weakness, so it will not put a global rise in the world as a priority, it just seeks a reasonable place in today's world. From this point of view, the New

7 Meeting during the author's visit to Serbia. Date:18 June 2016. 
Development Bank and AllB are designed to fill the investment gaps of existing financial institutes. These two new institutes cannot be compared with the IMF, or World Bank, since the latter are designed with many goals, not just investment, and their funds are linked with many political reform conditions. Such conditions are things China does not want to be get involved with.

What is more important is that in fact China is very cautious to avoid the effects of Western ways of thinking. In the history of Europe, Britain, Germany and France have been balancing each other for centuries, any alliance between two caused the third country to be suspicious. Any other country's rise will also cause the same thing. To these countries, power is an unchangeable fact, no matter with what kind of goal. Germany before World War One invested a lot and was very active in Europe and Africa, which caused other countries to form an alliance to balance against it. This is because they believed that in the future or some unpredictable time, Germany would develop hegemonic ambitions and become a threat. They had to defend against that threat in advance. Now, China is spreading its culture and investment all over the world, which to Europe, must be backed by great power. This great power will then change into a political and economic threat, like Germany in history.

But the facts are not like this. China knows exactly the logic behind this opinion, and to the greatest extent tries not to get involved in security problems in the world. Because China does have the ability to affect a country. Under these conditions, if China still actively participates in the Ukraine crisis, or the Syria crisis, and chooses a side to stand with, what will happen? If China begins to affect South-Eastern European politics, particularly when Russian influence is decreasing and Turkey's is increasing, what will happen? What would Germany, France or other countries think of China? If China gets involved in these issues, the Chinese action would be considered a way to drive Russia further away and block Turkey. That would be a really serious problem as China would no longer be able to implement the Belt and Road Initiative. So, China does not want this to come true and tries to stay far away from the politics of its foreign partners, and just focus on pragmatic cooperation. This is what China is doing now. Besides, China understands that investments or funds cannot change political trends or systems of its partners, and China does not want to do 
either. The EU must understand well the Chinese position considering the domestic political situation in Hungary and Poland. These two countries are still enjoying the EU's funds, but the funds cannot change Mr. Viktor Orban's and Mr. Lech Kaczynski's attitude. The same thing goes for China. Chinese investment cannot change its partners' attitudes towards some sensitive issues, like Tibet, Xinjiang or the South and Eastern China Sea. Chinese partners have their own opinions on these issues. China does not intend to change them. In this sense, CEE countries cannot be used as a way to broaden China's diplomatic options, to form a lobby inside the EU. Moreover, a lobby is a typical Western political tool. China prefers to exchange on the official level. Western countries still place their own concepts upon Chinese behaviour.

\section{The combination of domestic needs and foreign policy}

The third feature of foreign opinion is the combination of domestic needs and foreign policy. In fact, this can hardly be considered as a different perception between China and its partners, since foreign partners exactly understand this as the point of Chinese foreign policy. A popular Chinese political phrase is that we should combine two policies, the domestic and international. However, the perception of this point is different. To foreign partners, this is a relatively new perception. In the early days of the Belt and Road Initiative, almost all of them concentrated on the challenges of a certain country along the Belt and Road, such as the Central Asian countries or Russia. They said heterogeneity between China, Russia and its neighbours is the biggest problem in cross-border cooperation. But now, they have started to realize that the real challenges derive from China itself. China is surrounded with problems: on the sea there are the disputes of the southern and eastern China Sea; on land, there are the Tibet and Xinjiang separatists, and so on. These factors make people turn their attention to Chinese domestic problems. Now they are suspicious of Chinese national ability and sustainability. They think that China needs its domestic economy to support the go-out strategy, but inefficient reform lowers the ability to invest. This puts the prospect of the Belt and Road Initiative less likely than before. After publishing the thirteenth five-year plan, China stated clearly that investment will be further enhanced, which means it needs more capital and stronger domestic 
manufacturing ability. It makes the situation worse. That is why many foreign partners think that nationalistic sentiment and the Chinese government's large role are very dangerous or ineffective tools to gain domestic stabilization.

As for China, it is a totally different picture. Domestic stabilization is indeed the final goal of the Belt and Road Initiative, as propounded by most of the Chinese elites. The biggest challenge China faces is indeed the structural reform of its economic model from investment and export, to domestic consumption. But these cannot bring about negative effects on the Belt and Road Initiative. What is more, nationalistic sentiment and the strength of the Chinese government's role are still useful tools. Firstly, China initiated the Belt and Road Initiative to upgrade its industry, in the context of the 'world's factory' moving from China to other countries. China is not just an investor to pour out money, but also plans to learn high-tech and management experience at the same time, during the so-called fourth industrial revolution. Reform of the economy needs technology and management experience, so China will unite the whole country's strength to implement this initiative, by concentrating government and non-government resources. Although it suffers from its economic situation now, for long-term profit, it is worthwhile. Hence, the Belt and Road Initiative is not backed by the domestic economy, it is the tool with which to reform the domestic economy.

Secondly, to unite the Chinese people and government, to implement the Belt and Road Initiative, nationalistic sentiment and the Chinese government's large role are very helpful and not more dangerous than those in Europe or any other region, as people have imagined. The most important thing is that Chinese nationalism is not the "nationalism" described by western language. It is not about the majority nation and minority communities; it is about China itself. In the western description, other religions or other nations cause the problem, like Muslim refugees or Roma people. But when Chinese talk about nationalism, they mean China as a whole, or the Chinese people. There are 55 minorities and the Han nation in China, which is really rather complex when compared with other countries. The central government's minority policy focuses on tax-cuts, education priority and so on. The life of minorities really 
changed a lot since 1949. The Han nation as the biggest nation in China, and also shows an inclusive attitude towards minorities. So discrimination, or other western-style nationalisms is rare in China. However, the author cannot deny that indeed there are some cases of discrimination.

As for the Chinese government's role, the author thinks that it is very helpful to the implementation of the Belt and Road Initiative. The author even judges that without the strong role of government, the Belt and Road Initiative cannot be implemented smoothly. As we all know, the main feature of the Belt and Road Initiative is infrastructure projects, since China has much more experience in this area. It is hard to profit from these kinds of projects in the short term due to large initial costs. It is more like a social welfare project, rather than a pure marketoriented project like food trade. So, we cannot expect many private companies to invest in projects like this, the only way is for government or state-owned companies to get involved. Only these actors can focus on long-term profit, and are capable of handling a long capital chain. Besides, investing in another country is a risk. For Chinese private companies, especially under the current situation, they can hardly take risks, and they are not familiar with foreign laws, environments, and markets. Compare that situation with Europe, where it is easy for a German company to invest in Hungary, because they are both EU Member States, they are familiar with each other's laws and have had contact for centuries. That is the biggest weakness of Chinese investment. Under these circumstances, private companies will think it over and over again to avoid risks before investing. If the main Chinese actors of the Belt and Road Initiative are private companies, then this initiative cannot be implemented so fast and broadly. Or maybe, at that time, foreign partners will criticize the Chinese side as an unreliable partner, because the Chinese (private companies) would always want to find the most profitable projects. With these criticisms, how could China learn high-tech and management skills from the outside?

The role of the government is also another guarantee for the implementation of the Belt and Road Initiative. Contrary to foreign opinions on the role of the government as a low-efficiency phenomenon, it is a highly efficient actor. Take the process of railway construction, for 
example. In China, if the government plans to build a railway between two long-distance cities, which passes through several provinces, then central government will gather the heads of these provinces and formulate a plan, then assign tasks to these provinces. When a section of the railway is finished, all they need is a connection, the whole thing could be done in around one year. Compared with China, this kind of project is slow in foreign countries. Take the Baltic railway for example, this line was firstly proposed very early on to the EU, but work on the railway has not even started. Lithuania changed transition stations twice and the EU changed its commissioner for transportation, who moved this project from the top of the agenda. This can also be well illustrated by many cases in Central and Eastern Europe. More than 20 years have passed since, but connectivity in this region has still not improved by much. Every country has a large number of projects to change this situation, but either because of cost, or because of coordination between countries, many projects have just failed. From this point of view, the Chinese government shares its experience to its partners and uses its experience in cooperation with other countries. It can make sure that projects can be carried out without hesitation and delay, which is the basic pillar of mutual trust.

From the above, we can see that a combination of domestic needs and foreign policy is a common opinion about the Belt and Road Initiative. However, due to differing national economic conditions, China and its partners have different understandings of this point. According to Chinese economic conditions, the tools of nationalist sentiment and central government are useful tools which can help China to carry out its foreign policy, while this situation is different in foreign countries.

All in all, we can see from the above analysis that the difference between the perceptions of China and its partners towards the Belt and Road Initiative is based on their own experiences. Their different experiences of history, development, transition and other things, color their judgement of the Belt and Road Initiative, from which derive their different perceptions. The influence of great powers makes Chinese partners skeptical of its 'real' goal in this initiative. The transformation experiences of western-style economies makes them pessimistic to the Chinese domestic situation, and Chinese methods of implementation 
of this initiative. All of these factors cause different perceptions. Another factor is that although many Chinese elites do propagandize the Belt and Road Initiative, they always focus on "what this initiative is not", rather than "what this initiative is". It makes people more confused, and makes the meaning of this initiative more opaque. This makes the situation worse.

\section{Conclusion}

In this article, the author tried to explain the reasons and logic behind the different perceptions of China and its partners. As you can see from the above, the main reason is that the two sides cannot understand each other well enough. That is also why the Chinese side proposed five kinds of connectivity as part of the Belt and Road's goals, that is: trade links; capital flows; infrastructural investment; policy coordination; and people to people exchange. However, the author takes people to people exchange as the first priority. When we really see things from the point of view of others, we can find that there are some paradoxes as hard obstacles for mutual understanding, which the author has shown in the above sections.

The first paradox is about market need, trade volume and investment modes. Many western countries always express concern about the Chinese way of investment and trade, as mentioned above. For example, in the CEE region, Poland complains about the trade deficit, Hungary complains that there has been no more greenfield-investment since 2009. However, firstly, trade is decided by the needs of the market. Poland has a big trade deficit with China, which means Polish products export less to China. The fact is that the Chinese market needs less Polish products. The famous Polish apple is not tasty for Chinese people. The EU and some European countries always stress the market economy status is not proper in China and that the Chinese economy is not open enough. But it seems that on the issue of trade deficit, they never realize what the market needs. If China will subsidize imports from Poland, the trade deficit will improve, but China will be faced with more critics. Secondly, the author has said in the 
second part of the paper that the mode of investment of mergers and acquisitions is much safer for Chinese to invest in. Besides, mergers and acquisitions is a reasonable method in global business. So the first paradox is that when China behaves according to international rules or norms, its partners still criticize China. When China behaves in another way, they criticize even worse.

The second paradox is about ideology and Chinese intentions. These factors are combined together. Chinese partners take China as a big new power in the world, a status which requires China to take a role in some issues of global conflict. For example, in the Ukraine crisis, China chose a neutral position, which makes many countries unsatisfied. They consider it an irresponsible action by China. The deeper reason for this is that as a different ideological body, China's choice is important. In the cooperation with EU and European countries, the issue of ideological difference is always the first thing, like the cooperation with the Czech Republic, or with the European parliament. China has realized that avoiding the use of ideological words as much as possible in the international society alleviates this issue. China also puts pragmatic cooperation on the top of its agenda to make its partners not focus on ideological topics. China wishes to make a pragmatic environment to ensure the development of itself and its partners. But for Chinese partners, they perceive all moves by China as ideological ones, and their conclusion therefore is that of growing Chinese geopolitical ambition. They cannot split Chinese ideology and government policy, including in the Belt and Road Initiative, and $16+1$ cooperation. Here is the paradox, if China chose to take part in the Ukraine crisis, or the Syria crisis, and condemn Russia, the USA or the EU, international society will definitely perceive this choice as a manifestation of ideologically charged Chinese geopolitical ambition.

The third paradox is about efficiency and the Chinese way of cooperation. The Chinese way is government-oriented. The government drives stateowned companies and its policies drive people. In China, a high-level official visit is the most important thing that can happen to a region. It is even a signal to businesses and an opportunity for cultural exchange. This is the impression of western countries to China. But the western way is totally different, where the influence of government is less. All of these factors make Western countries think that the Chinese way of cooperation is hard 
to accept, since big companies are backed by Chinese government and not driven by the market. However, as the author mentioned above, Chinese government-led cooperation is highly efficient and short-term profit is not the main focus of this kind of cooperation. So, this is the main worry of Western countries but, at the same time, the biggest advantage of cooperation with China. If the body of cooperation is private enterprise, which concentrates on short-term profit, it can hardly invest in a power plant, highway, railway and so on, of course, except for several big multinational groups. If left to private companies, then the whole of the Belt and Road Initiative and 16+1 cooperation will never come to fruition. Under such circumstances, efficiency is low and foreign partners will complain more about the Chinese side. This is the third paradox, the role of Chinese government and the method of cooperation in the western imagination.

These paradoxes are the problems which, it seems, cannot be solved. According to the author's opinion, they are deeply rooted in the definition of "development". In China, economic development, the material improvement of people's lives is the first priority in "development". If people's lives improve and its economy blooms, all problems will be solved. However, in European countries, or in the western way, economic development is just part of "development". Human rights, democratic reform, and other related issues should be developed at the same time. Economic development does not necessarily bring about improvement in these areas. That is why China intends to focus on pragmatic cooperation under the Belt and Road Initiative and 16+1 cooperation, but its partners criticize the Chinese on other issues not related to pragmatic cooperation. In the future, how the two sides perceive each other's ways of thinking is the biggest challenge on the Belt and Road Initiative and 16+1 cooperation. 


\section{Bibliography}

Brockova, K. and Gress, M., 2016. The Possibilities of Further Promotion of Cooperation of China and Slovakia within the ' $16+1$ ' Format. Conference Paper.

Duchâtel, M., Bräuner, O. and Hang, Z., 2014. Protecting China's Overseas Interests: The Slow Shift away from Non-interference. Sweden: SIPRI.

EY, 2015. Western Europe overtakes China and North America as \# 1 investment destination with FDI projects at record high. EY, [online] 27 May. Available at: http://www.ey.com/gl/en/newsroom/newsreleases/news-ey-western-europe-overtakes-china-and-northamerica-as-number-1-investment-destination [Accessed 25 June 2016].

González-González, E. and Nogués, S., 2016. Regional polycentricity: an indicator framework for assessing cohesion impacts of railway infrastructures. European Planning Studies, 24(5): 950-973.

Jackson, J. K., 2013. U.S. Direct Investment Abroad: Trends and Current Issues. Congressional Research Service, [pdf] 11 December. Available at: http://fas.org/sgp/crs/misc/RS21118.pdf [Accessed 10 June 2016].

Kissinger, H., 2012. Diplomacy. Hainan: Hainan Press.

Kissinger, H., 2011 . On China. New York: Penguin.

Ojala, L., Kersten, W. and Lorentz, H., 2013. Transport and Logistics Developments in the Baltic Sea Region until 2025. Journal of EastWest Business, 19(1-2): 16-32.

Rudzki, P., 2016. Góra złych długów w Chinach. RP, [online] 18 May. Available at: http://www.rp.pl/Finanse/305189950-Gora-zlychdlugow-w-Chinach.html [Accessed 23 June 2016].

Sørensen, C. T. N., 2015. The Significance of Xi Jinping's "Chinese Dream" for Chinese Foreign Policy: From "Tao Guang Yang Hui" to "Fen Fa You Wei". The Journal of China and International Relations, 3(1). 
Tianping, K., ed., 2015. The evolution of Višegrad Group and China-V4 cooperation. Beijing: China Social Sciences Press.

Waszczykowski, W., 2016. The speech in Chinese Academy of Social Sciences. 25 April 2016.

Weissmann, M., 2015. Chinese Foreign Policy in a Global Perspective: A Responsible Reformer "Striving For Achievement", China and Russia - A Study on cooperation, competition and distrust. Stockholm: Swedish Defense Research Agency.

Yan, X., 2014. From Keeping a Low Profile to Striving for Achievement. The Chinese Journal of International Politics, 7(2): 153-84.

Ma Junchi (majc@cass.org.cn) is Assistant Professor at the Institute of European Studies, Chinese Academy of Social Sciences. He has been at CASS since 2014. He also works in the China-CEE Institute as researcher in Budapest, Hungary. His field of expertise focuses on CEE countries. His research areas include 16+1 cooperation, the Belt and Road Initiative, CEE transition and transition economy. He has participated in many research project funded by Chinese ministries and local provincial government. He was a visiting scholar in Slovenia and Hungary. He speaks Hungarian and English. 